\title{
Animal and Human Digestive System Material of the Fifth Grade Elementary School in the form of Pop-Up Book Media
}

\author{
Dewa Ayu Putu Mega Noviyanti \\ Study Program of Primary School Education Teacher, Ganesha University of Education \\ Email: meganovi20@yahoo.com \\ I Gede Margunayasa \\ Study Program of Primary School Education Teacher, Ganesha University of Education \\ Email: igede.margunayasa@undiksha.ac.id
}

\section{A R T I C L E I N F O \\ Article history: \\ 1 Maret 2020 Received in revised form \\ 30 Maret 2020 \\ Accepted 11 April 2020 \\ Available online 15 \\ Mei 2020 \\ Kata Kunci: \\ Buku Pop-Up, Pencernaan \\ Hewan dan Manusia.}

Keywords: Pop-Up book, and human digestive system of animal

\begin{abstract}
A B S T R A K
Terbatasnya sumber belajar yang relevan dan kurangnya pengembangan materi muatan IPA pada topik sistem pencernaan hewan dan manusia menjadi alasan penelitian ini dilakukan. Penelitian ini bertujuan untuk mengembangkan media pop-up book pada topik sistem pencernaan hewan dan manusia kelas V SD yang telah teruji validitasnya. Penelitian ini adalah penelitian pengembangan dengan menggunakan model analyze, design, development, implementation, dan evaluation. Namun tahap implementasi dan tahap evaluasi tidak dilaksanakan karena keterbatasan waktu. Metode pengumpulan data yang digunakan dalam penelitian pengembangan ini adalah metode kuesioner. Subjek penelitian ini adalah media pembelajaran berupa pop-up book pada topik sistem pencernaan hewan dan manusia kelas V SD dan objek penelitian ini adalah validitas media pembelajaran media pop-up book pada topik sistem pencernaan hewan dan manusia kelas V SD. Instrumen yang digunakan dalam penelitian pengembangan ini adalah rating scale. Dari hasil penilaian oleh empat orang ahli, diperoleh skor rata-rata sebesar 4.79 dengan kualifikasi sangat baik. Berdasarkan hasil penilaian tersebut, dapat disimpulkan bahwa media pop-up book pada topik sistem pencernaan hewan dan manusia kelas V SD valid dengan kualifikasi
\end{abstract} sangat baik. Adanya media pop-up book yang berguna untuk membantu tugas guru pada pelaksanaan pembelajaran khususnya dalam mengembangkan materi IPA pada topik sistem pencernaan hewan dan manusia.

\begin{abstract}
A B S T R A C T
The limited relevant learning resources and the lack of development on natural science content on the topic of the animals and human digestive system were the reasons for this research. This research aimed at developing Pop-Up book media on the topic of animal and human digestive system in which the validity had been tested. This research was developmental research by using some steps, such as analyze, design, development, implementation, and evaluation models. However, the implementation steps and the evaluation steps were not conducted due to time limitations. The data collection method used in this research was a questionnaire method. The subject of this research was a learning media in the form of a Pop-Up book on the topic of animal and human digestive system on the fifth-grade elementary school students and the object of this research was the validity on learning media for Pop-Up book media. The instrument used in this developmental research was the rating scale. From the results of the assessment by four experts, an average score of 4.79 was obtained into very good qualification. Based on the results of the assessment, it could be concluded that the Pop-Up book media on the topic of animal and human digestive system was valid with a very good qualification. The existence of a Pop-Up book media was useful to assist the teachers' tasks in implementing learning specifically in developing natural science materials on the topic of animal and human digestive system
\end{abstract}

\section{Introduction}

Teaching-learning is a series of activities that are designed for the students to enable the learning process (Suwatra, et al., 2017). Teaching-learning activities at every level of the school are certainly different. These differences depend on the characteristics of students and their learning needs. Elementary school students are generally in the range of ages 7-13 years. At this age, students are still at a stage of concrete operational development. Children at this age have understood the mathematical symbols but have not dealt with abstract things (Alfin, 2015). Elementary school students generally have the nature of fun playing and love to feel or do something directly (Indriani, 2014). Looking at the characteristics of the development stage, the teachinglearning activities of the elementary school students should be designed in such a way to fulfill the learning needs.

To make students learn well, students need the learning facilities such as learning resources and media. Learning resources are all things that deliver messages or learning materials to be presented directly by 
themselves or with intermediaries in the form of tools (Hafid, 2011). The main learning resource that becomes the reference for student learning at school is the thematic book of 2013 Curriculum. The book has undergone several revisions to make it more perfect and suit for the science development and students' learning needs. Thematic Book of 13 Curriculum is composed of several subject matters which are packaged in a certain theme. Through a combination of several materials from different subject matters, it makes this book looks more practical and efficient for teaching and learning activities. Instead of its practical use, there are still weaknesses of the thematic book of 13 Curriculum. The presented material seems too concise on certain learning content. The role of learning resources in developing various desired competencies of a subject is as a provider of diverse information and knowledge (Jailani \& Hamid, 2016). A good learning resource should be able to provide the information that is needed by students, instead of providing narrow information and make it difficult for students to answer their curiosity. Thus, the learning process of learning resources has an important role.

Learning resources as a very important component in learning activities, need to be supported by the use of learning media to convey the information from learning resources properly. Learning media is a means to facilitate student learning (Anwas, 2011). Learning media can be the function as a learning attraction to foster students' interest in learning (Ramayulis, 2018). Similar to learning resources, learning media also needs to be adjusted to the students' interests, needs, and characteristics. The use of learning media can make the learning atmosphere more interesting, happy, and enjoyable. From the various benefits of using media, there are still teachers who have not used media assistance in implementing teaching and learning activities.

The use and utilization of learning resources in elementary schools are not optimal yet, it can be seen from the students' books in elementary schools that are still lacking in the concept and material studies. This statement is supported by the results of observation and interviews that had been conducted. The result of the interview showed that the fifth-grade elementary school teachers in the Cluster found out a concise subject matter. The material taught by the teacher to students was generally taken from students' books. It causes the limitations of learning material and student knowledge. In addition, teachers also rarely use the media in teaching and learning activities for various reasons. The main reason for misusing the instructional media is because the appropriate learning media are not yet available in schools. Therefore, teachers do not have enough time to develop their media. Observation results showed that student learning activities seemed monotonous without learning media and there were no attractive intermediaries in delivering material to students. One of the materials that are still too narrow in the thematic book of 13 Curriculum is a science material on the topic of animal and human digestive systems of the fifth grade. Based on the result of a questionnaire that was distributed to teachers and the fifth-grade students of the Elementary School Cluster VIII of Sukasada District. It showed that $80 \%$ of teachers and $66.7 \%$ of students stated that the learning material in students' books was less extensive. $80 \%$ of teachers and $73.3 \%$ of students stated that the science content material of students' books strongly agreed to be developed in the form of media. In addition, $60 \%$ of teachers and $73.3 \%$ of students stated that the learning material of students' books needed to be developed. If this problem is ignored, it will impact on students' material understanding that must be mastered, students will know or understand a small portion of the material. In addition, it will affect the learning process later at a higher level, and the development of students' learning outcomes. Therefore, it is necessary to develop a learning media which includes the development of learning materials in students' books. An interesting learning media that can cover material development in students' books is the pop-up book media.

A pop-up book is a book in which there are folded pieces of images appear in three dimensions when the page is opened (Devi \& Maisaroh, 2017). The appearance of the pop-up book media that can bring up images and move in three dimensions make students curious to open and read page after page of the book. Pop-up book media is a media that can explain the material thoroughly and make students active during the learning process (Ruiz, et al., 2015). Pop-up books are a form of interesting paper folding crafts that can cause three-dimensional shapes when the paper is opened and it will fold flat when the paper is closed (Iizuka, at al., 2011). Pop-up books can be designed for the needs of the material being taught for students. Considering the aim of developing material, learning material can be developed as a whole unit in pop-up book media. Three-dimension elements on every page of a pop-up book can cause curiosity of the reader to open each page. Thus, by using the pop-up book media, the learning process becomes more interesting because it can increase students' curiosity. Pop-up book media which is packed with unique, interesting colors and shapes can make students eager to read it. The surprise on every page will also make the reader feel curious to open one page of the book to the next page (Khoirotun, et al., 2014). Since elementary school students have high curiosity, like colorful objects, and they are happy to do something new. Then, the pop-up book media is very suitable as a means of learning in elementary schools.

Several studies on pop-up books include Sholikhah Sholikhah (2017). A study was conducted to a large group with a total average of $96.9 \%$. It showed that pop-up book media could increase student interest in learning. A study was conducted by Masturah, et al., (2018), based on the study results of data analysis, it explained that pop-up book learning media was declared valid and could be useful for students in the learning 
process and improved learning outcomes in the material content of the third grade A students of Mutiara Singaraja elementary school. It was proven based on the results of expert tests and trials for students. The results showed the average percentage was in the range of 90\%-98\% with very good qualification. Therefore, it can be concluded that the pop-up book learning media is very well used in the teaching and learning process and can improve student learning outcomes. In addition, a study conducted by Khoiriyah et al. (2018) showed that the results obtained through the development of pop-up book media were valid with an average percentage of $87 \%$ and very good qualification. The average percentage of product feasibility level was $83.07 \%$ of valid category. Based on the results of the validity test, it can be concluded that the development of material with pop-up book media was very suitable for learning activities and increased students' interest in learning. Thus, it can be said that the development of pop-up books has a positive impact in the learning process so that the media pop-up book can be developed on the topic of animal and human digestion related to the purpose of this study, namely to determine the validity of the pop-up book media on the topic of the animal and human digestive system and human of the fifth grade students of the elementary school in Cluster VIII Sukasada District in 2019/2020 academic year.

The development of pop-up book media was conducted by using the ADDIE model which consists of 5 stages, namely: (1) analyze, (2) design, (3) development, (4) implementation, and (5) evaluation. However, in this study, the implementation and evaluation stages were not conducted due to time, cost, and resource limitations. Techniques in making pop-up book media are very diverse such as (1) Transformations, the form of pop-ups consisting of vertical pieces, (2) Volvelles, the shape of pop-ups using circular elements in the making, (3) Peepshow, a pop-up is composed of paper piles that are arranged stacked together to create elements of depth and perspective, (4) Pull-tabs, a sliding paper tab or shape that is stretched and pushed to show new image movements, (5) Carousel, a technique uses ropes, ribbons or buttons that when it is opened and folded back in the form of complex objects, (6) Box and Cylinder is the movement of a cube or tube that moves up from the middle of the page when the page is opened. The technique used in the development of pop-up book media on the topic of animal and human digestive systems applied peepshow and pull-tabs techniques. The development of this learning media was limited to pop-up book media on the topic of animal and human digestive systems of the fifth grade elementary school in Cluster VIII of Sukasada District in 2019/2020 school year. Based on the results of this presentation, this study developed a pop-up book learning media on the topic of animal and human digestive systems of the fifth grade elementary school Cluster VIII Sukasada District in the academic year 2019/2020.

\section{Method}

This study was a developmental research of pop-up book media on the topic of animals and human digestive system of the fifth-grade elementary school. The model used in this study was the ADDIE model (analyze, design, development, implementation, evaluation). The selection of this model was based on the consideration that this model was developed systematically and rested on the theoretical foundation of learning design (Tegeh \& Jampel, 2014). This model was programmed in a systematic sequence of activities to solve learning problems related to learning resources that were appropriate to the needs and characteristics of learning (Tegeh \& Jampel, 2017). The development of pop-up book media on the topic of animals and human the digestive system was conducted through several stages. The implemented stages were, namely: (1) analyze, (2) design, and (3) development.

In the analyze stage, needs analysis was conducted, namely: teacher and student book analysis, students' characteristics analysis, curriculum analysis, and analysis of the ways and conditions for making media. The design stage was conducted in the design of pop-up book media on the topic of animal and human digestive system, which included basic competency, indicators of competency achievement, and sketches of pop-up book media. After the media had been designed, it was continued to the media development stage, the development stage was conducted by developing pop-up book learning media on the topic of animal and human digestive systems.

The subject of the present study was a learning media in the form of pop-up book media on the topic of animal and human digestive systems of the fifth-grade elementary school. The object of study was the validity of pop-up book learning media on the topic of animal and human digestive system of the fifth-grade elementary school. The data collection method used in this media developmental research was a questionnaire method. The questionnaire method is conducted by giving a set of statements or written questions to be answered by respondents (Agung, 2014). The instrument used in this developmental research was a rating scale. The rating scale is a valuation technique using a certain scale as a reference from the lowest level to the highest level 
(Ilhami dan Rimantho, 2017). In this study, a rating scale of 1-5 was interpreted descriptively from very poor to very good. Media assessment refers to validity aspects including format, content, language, practical, and effective aspect (Yamasari, 2010). The five aspects were made in the form of instruments based on the criteria of each aspect which included: (1) criteria for format aspects, such as color, text, letters, and layout; (2) criteria for the content aspect, such as the suitability of the material with the indicators, the ability of the media to explain the material, the completeness of the material, and the attractiveness of the material to the media; (3) language aspect criteria, such as language use, language standardization, sentence effectiveness, and word usage; (4) criteria for practical aspects related to media use; and (5) the criteria of effective aspects related to the use of media (Monika, et al., 2014). The evaluation instrument was tested for eligibility by content validity test after an assessment was given by an expert using the Gregory formula. Based on the results of the validity test, the validity coefficient of the instrument was 1.00 . The instrument validity coefficient was classified based on the content validity of coefficient criteria so it can be seen that the coefficient was in the range of $0.80-1.00$, which meant that the classification of content validity was very high. After the instrument was valid, then the media assessment was assessed by four experts whose results were in the form of scores, input, criticism, and suggestions for the media pop-up book.

Data analysis methods used in this developmental research were qualitative descriptive statistical analysis and quantitative descriptive statistical analysis techniques. Qualitative descriptive statistical analysis methods were used to process data in the form of input, responses, criticisms, and suggestions from the results of experts' reviews toward media and learning material developed through the provision of media assessment sheets and learning materials. Quantitative statistical analysis methods were used to describe the average score of each learning expert related to the developed media. Learning media was stated valid if the average results in each pop-up media book on the topic of animals and human digestive system were at least in good qualifications with a range of $3.01<\times \leq 4.01$.

\section{Result and Discussion}

The needs analysis that was conducted including the questionnaire distribution to teachers and the fifthgrade students in the Cluster VIII of Sukasada District, related to the need for media and science content material development in student books. The results of the needs analysis indicated that the teacher did not have a learning media for the science content and material in the student book that was incomplete, less extensive, and less deep. The analysis of students' characteristics was needed to determine students' understanding of the developed popup book media. The analysis result of students' characteristics of the elementary school in Cluster VIII Sukasada District showed that the students had good reading skills and had an interest in interesting media with striking colors. The fifth-grade elementary school students in Cluster VIII Sukasada District were on average 11 years old, therefore learning should use learning resources that are interesting for students. Curriculum analysis was carried out to determine the material contained in the designed instructional media, namely by analyzing Core Competency (CC), Basic Competency (BC), and indicators of learning objectives as a basis for making pop-up book media. The results of curriculum analysis on basic competencies were translated into several indicators that were used as a reference in developing learning materials. In this developmental research, CC, BC, and developed Competency Achievement Indicators were the topic of animal and human digestive systems. An analysis of the ways and conditions for making media was conducted to determine the conditions for good media and as a reference (guidelines) for media development to develop a good and relevant media. The results of condition and ways for making media were based on aspects of format, content, language, practicality, and effectiveness of media use. A developed learning media should refer to the VISUALS principle, which stands for Visible (easy to see), Interesting, Simple, Useful (useful content), Accurate (true/accountable), Legitimate (reasonable/legal), and Structured (structured/well-structured) (Nurseto, 2011). The analysis of teachers' books and students' books were conducted to find out the scope of the science content material so that it can be known the developed material. The results of teachers' and students' books analysis were learning materials in student books that were less extensive, incomplete, and lacking in depth so it is necessary to develop learning materials especially on the topic of animal and human digestive systems.

At the design stage, it was conducted on the pop-up book media on the topic of animal and human digestive system of the fifth-grade elementary school. This activity started with determining BC (basic competency) and indicators of competency achievement. It was followed by designing sketches of pop-up book media. After the initial product in the form of a sketch was completed, it was continued by consulting to the supervisor about the sketch that had been designed to obtain input or suggestions so that, the improvements 
could be done and went to the stage of media development. The details of the developed design consisted of 11 pages which included: (1) book cover; (2) BC (Basic Competency), indicators of competency achievement, media usage guidelines, and table of contents; (3) 9 pages of animal and human digestive system material; (4) practice questions; and (5) back cover. Pop-up books were made in three-dimensional shapes and covered by images on each page.

The development stage was conducted through the activity development of pop-up book learning media design that had been consulted to the supervisors to revise the existing deficiency. After revising and developing, an expert test was conducted to review the developed media. The expert test was done by giving an assessment sheet to four experts, namely two lecturers and two teachers of the fifth grade. The obtained data in the form of scores on the media assessment sheet that had been assessed by experts were analyzed to determine the validity of the developed media. Based on the analysis of pop-up book media validation data, the average score of media validation was in the range of $4.01<\mathrm{X}<5.01$ with "very good" qualifications. Overall, the average score of popup book media validation was 4.79 , when it was converted to a five-scale conversion guideline in the score range of $4.01<\mathrm{X} \leq 5.01$ with "very good" qualifications.

The developed pop-up book had a size of 21.0 x $14.8 \mathrm{~cm}$ (A5). Pop-up books were made with bright and attractive colors to motivate students to use media. A glossy, A4 rigid, and sticker paper were used to make media. The image of media was taken from the internet. The image was based on the design that was created by utilizing the Adobe Photoshop CS-Middle East Version, Adobe Image Ready CS-Middle East Version, dan Microsoft Office PowerPoint 2010. The image of pop-up book media on the topic of animals and human digestive system that had been developed and tested for validity can be seen in Figure 01 .

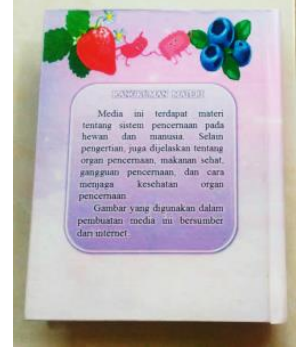

(a)

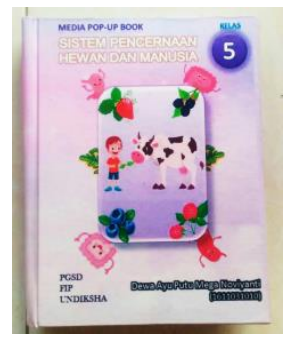

(b)

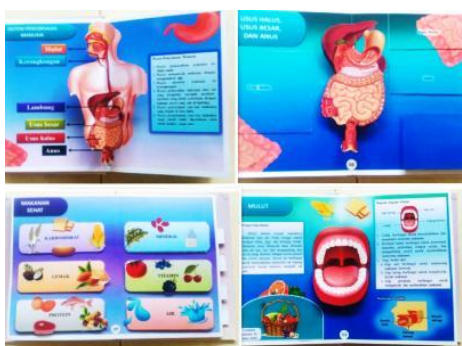

(c)

Figure 01

(a) back cover, (b) front cover, (c) the example of content pages

Based on the results of four experts' assessments, an average score of 4.79 was obtained. The average results were converted into a five-scale conversion and they were in very good qualifications. The average validation results of expert test scores can be seen in Figure 02.

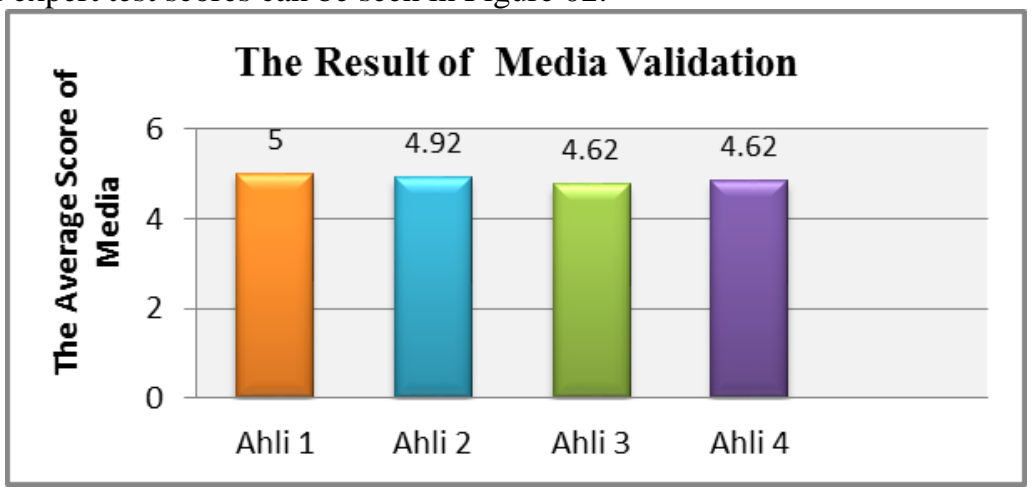

Figure 02

The Result of Media Validation

Based on the average validation results of expert test scores on the diagram, it was known that the media pop-up book on the topic of animal and human digestive systems got an average validation score, namely 
expert 1 got an average score of 5, expert 2 got an average score of 4.92, expert 3 got an average score of 4.62, and expert 4 got an average score of 4.62. The average validation score of each expert when it was converted to a five-scale conversion guideline was in the score range of $4.01<x \leq 5.01$ so that the media had very good qualifications.

The present study developed pop-up book media on the topic of animals and human digestive system of the fifth-grade elementary school. This developmental research model applied the stages of the ADDIE model (analyze, design, development, implementation, evaluation). However, this study was conducted only at the development stage. It was because of the limitation of time, finance, and resources. The use of the ADDIE model in this study was because the ADDIE model had a sequential or systematic step and it was based on theoretical learning design. ADDIE model can be used as an effort to overcome learning problems, especially in learning resources that were considered to students' characteristics, needs, and learning materials.

At the analysis stage, needs analysis, analysis of teachers' books and students' books, student characteristics, analysis of ways and conditions for making media, media analysis, and curriculum analysis were conducted. Based on the analysis results, the data media design toward the existing problem was obtained. Based on the analysis results, it was found that the science content learning material was less extensive, less complete, and lacking in depth so that, the science content learning material on the topic of animal and human digestive systems needs to be developed in the form of pop-up books learning media. Pop-up book is a book-shaped media in which it can present folds of three-dimensional pictures if the pages are opened (Devi \& Maisaroh, 2017). Elementary school students have understood mathematical symbols but have not dealt with abstract things (Alfin, 2015). It is because three-dimensional images appear more real and can concretize objects comparing to images in two-dimensional books. The results of needs analysis were used as a reference in developing media. There was a thing that distinguishes the material in students' books with the developed material in media pop-up book, namely: (1) the students' book did not explain the organs of the digestive system, whereas the part of the digestive system was explained in pop-up book media; (2) only three examples of the digestive system diseases were given, whereas eight examples of the digestive system diseases were explained along with how to prevent the disease; (3) in the students' book, only a few function of the digestive organs were explained, whereas in the pop-up book media, the functions of all digestive organs were explained; (4) the example of healthy food is only mentioned in carrots and cassava in the students' book, while in the pop-up book media, it explained about carbohydrates, fats, proteins, minerals, vitamins, and water along with examples of healthy food. An additional material in the media pop-up book was used to support the limitations of the material in students' books, namely through electronic books that discussed the digestive system material for the fifth-grade elementary school.

The design stage was done by designing the pop-up book media on the topic of animals and human digestive system of the fifth-grade elementary school. This activity started with determining BC (basic competencies) and indicators of competency achievement and it was followed by designing sketches of pop-up book media. After the initial product in the form of a sketch was completed, it was continued by consulting to the supervisor about the designed sketch to obtain input or suggestions so that improvements could be conducted. The developed pop-up book had a size of $21.0 \times 14.8 \mathrm{~cm}$ (A5) with a total of 11 pages including (1) book cover; (2) BC (basic competency), indicators of competency achievement, media usage guidelines, and table of contents; (3) 9 pages of animal and human digestive system material; (4) practice questions; and (5) back cover. Pop-up books were made in three-dimensional form and contained images on each page. Pop-up books were made with bright and attractive colors to motivate students to use media. After the media design stage, then it proceeds with the development stage of media.

The development stage was conducted through the development activities of pop-up book learning media design that had been consulted with supervisors to correct the existing deficiencies. After it had been corrected, an expert test was conducted to review the developed media. The expert test was carried out by providing an assessment sheet with 13 points of assessment aspects which contained the feasibility of pop-up book media on the topic of animal and human digestive system of the fifth-grade elementary school to two lecturers and two teachers of the fifth grade. To get an optimal produced media, the criticism and suggestions from lecturers and teachers that contained the development of media pop-up books were needed. The data result of the experts' reviews was analyzed to determine the validity of the media and learning material that had been created and developed. The instructional media was improved based on input and advice given by the expert. Media assessment refers to validity aspects which included format, content, language, practical, and effective aspects (Yamasari, 2010). Based on the results of experts' reviews, the developed pop-up book media had fulfilled validity aspect of media assessment. The average validation results of experts' test scores found that the pop-up book media on the topic of animals and human digestive system got an average validation score, namely, the $1^{\text {st }}$ expert got a maximum total of 65 with an average score of 5, the $2^{\text {nd }}$ expert got the total number of 64 with an average score of 4.92 , the $3^{\text {rd }}$ expert got a total of 60 with an average score of 4.62 , and the $4^{\text {th }}$ expert got a total of 60 with an average score of 4.62. Based on 13 aspects of the assessment, the first and second aspects related to the media coverage of each expert for each aspect and the total was 19 . It showed that the identity and 
attractiveness of the cover still needed attention. The third, fourth, and fifth aspects were related to the format of media display. The fourth aspect got a maximum score with a total of 20, while the third aspect got a total score of 19 , and the fourth aspect got a total score of 18 . It showed the harmony of colors, writing, and images on the media still were needed attention. The sixth, seventh, and eighth aspects were related to the content or material contained in the media. The sixth aspect got a total score of 19, while the seventh and eighth aspects got a maximum score of 20. It showed that the suitability of the material with indicators of competency achievement needed to be considered. The ninth, tenth, and eleventh aspects were related to linguistic rules. The ninth and tenth aspects got a total score of 19, while the eleventh aspect got the lowest total score from other aspects of 17 . It shows that language rules still needed attention. The twelfth and thirteenth aspects were related to the practicality and effectiveness of the media. Both aspects had received a maximum score with a total score of 20 . The results of media validation analysis obtained an average score of pop-up book media validation in the score range of $4.01<\mathrm{X} \leq 5.01$ with "very good" qualifications. Overall, the validation average score of pop-up book media was 4.79 , when it was converted to a five-scale conversion guideline in the score range of $4.01<\mathrm{X} \leq 5.01$ with "very good" qualifications. Based on explanation above, the pop-up book media had been tested for its validity.

The advantage of the developed pop-up book media is that the media can present three-dimensional images based on the material taught by using bright colors. Elementary school students have understood mathematical symbols but have not dealt with abstract things (Alfin, 2015). By using three-dimensional images, students more easily understand the presented images. It is because three-dimensional images appear more real and can concretize the difficult objects comparing to images in two-dimensional books. Another advantage of the developed pop-up book media is that the pop-up book media is made with various techniques, namely: (1) peepshow, the technique of making pop-up by compiling or stacking paper to create the deep illusion; and (2) pull-tabs, a pop-up technique by creating a paper tab so that it can be shifted, pulled, pushed so that it causes new movements and images. Elementary school students generally have the nature to play or do something directly. By using various pop-up techniques, the media becomes more interesting and can increase student activity and provide new experiences to students because it can involve students in using media during the learning process, such as shifting the pop-up book section, opening pages, and folding the pop-up book. Pop-up books can be designed based on the material needs that must be taught by students and pay attention to how the student's learning steps are. Pop-up book media can provide a special experience for students because it involves students in the use of media during the learning process, such as sliding, opening, and folding the pop-up book section (Safri, et al., 2017). Pop-up book display can be an advantage because it looks unique and different from other two-dimensional learning media. This pop-up book has a three-dimensional image that can arise when a page on the pop-up book is opened. The superiority of the pop-up book media that is associated with the theory of the elementary school student characteristics can support the development of a created pop-up book media because the created pop-up book media has been adapted to the needs and characteristics of the elementary school students so that the pop-up book media can be used optimally in learning activities. The shortcomings of the pop-up book media on the topic of animals and human digestive system of the fifth grade of the elementary school, which have not been tested directly at school. Updated developed pop-up book media compares to other pop-up book media, namely: developed pop-up book media in this study presents material about animals and human digestive system of the fifth-grade elementary schools that have never been made in the form of media pop-up book.

The results of the study are in line with a study conducted by Sholikhah, (2017). The results of data analysis obtained through the results of the pop-up book media trial showed that students' responses were positive, with an average total percentage of $87.5 \%$. The study was conducted on large groups with an average total percentage of $96.9 \%$. It shows that the pop-up book media can increase students' interest in learning (Sholikhah, 2017). A study conducted by Masturah, et al., (2018) is also in line with this study. Based on the results of research analysis, it explained that the learning media pop-up book was stated valid and useful for students in the learning process as well as improve learning outcomes in the material content of the third grade A students in Mutiara Singaraja Elementary School. It was proven based on the results of expert tests and trials for students. The results showed that the average percentage was in the range of $90 \%-98 \%$ with very good qualifications. Therefore, it can be concluded that the pop-up book learning media is very well to be used in the teaching and learning process and it can improve student learning outcomes (Masturah, et al., 2018). In addition, a study conducted by Khoiriyah, et al. (2018) is also in line with the present study. In this study, the results of pop-up book media development were valid with an average percentage of $87 \%$ and very good qualifications. The average percentage of product feasibility level was $83.07 \%$ and in the valid category. Based on the results of the validity test, it can be concluded that the development of material with pop-up book media is very suitable for use when learning activities as well as increasing students' interest in learning (Khoiriyah, et al., 2018).

Based on the three relevant study results, the developmental research of pop-up book media on the topic of the animals and human digestive system has never been developed and discussed so researchers conducted 
study on the development of pop-up book media on the topic of animals and human digestive system. And the relevant research results show that the development of pop-up book media is valid, efficient, practical (easy), and effective and it can explain learning material, motivate students, and improve learning outcomes.

\section{Conclusion and Suggestion}

Based on the results and discussion, it can be concluded that the results of the pop-up book media assessment on the topic of animals and human digestive system in the fifth-grade elementary school through four experts are valid with an average score of 4.79 with very good qualifications. The developed pop-up book media deserve to be further tested at the implementation stage to determine the effectiveness of the media in learning activities in the fifth-grade elementary school. The suggestions based on the process and results of the study can be seen as follows: (1) to the teacher, in conducting the learning process, the teacher can use the pop-up book media in this study as a reference in teaching the material content of science on the topic of the animal and human digestive system; (2) to the principal, the principal should facilitate the teacher in developing learning materials in the form of innovative learning media to create more effective learning; (3) other researchers who want to conduct a study into the development of instructional media can make this research as a reference related to similar research. Other researchers can continue this study to the implementation stage.

\section{References}

Agung. (2014). Metodologi Penelitian Pendidikan. Malang: Aditya Media Publishing.

Alfin, J. (2015). Analisis karakteristik siswa pada tingkat sekolah dasar. Prosiding Halaqoh Nasional \& Seminar Internasional Pendidikan Islam, 190-205.

Anwas, O. M. (2011). Lingkungan sebagai Media Pembelajaran dan Pengaruhnya terhadap Kompetensi Penyuluh Pertanian. Jurnal Pendidikan dan Kebudayaan, 17(3), 283-290.

Devi, A. S., \& Maisaroh, S. (2017). Pengembangan Media Pembelajaran Buku Pop-Up Wayang Tokoh Pandhawa pada Mata Pelajaran Bahasa Jawa Kelas V SD. Jurnal PGSD Indonesia, 3(2).

Hafid, H. ab. (2011). Sumber dan Media Pembelajaran. Jurnal Sulesana, 6(2), 69-78.

Iizuka, S., Endo, Y., Mitani, J., Kanamori, Y., \& Fukui, Y. (2011). An interactive design system for pop-up cards with a physical simulation. Visual Computer, 27(6-8), 605-612. https://doi.org/10.1007/s00371-0110564-0

Ilhami, R. S., \& Rimantho, D. (2017). Penilaian Kinerja Karyawan dengan Metode AHP dan Rating Scale. Jurnal Optimasi Sistem Industri, 16(2), 150-157.

Indriani, D. S. (2014). Keefektifan Model Think Pair Share Terhadap Aktivitas dan Hasil Belajar IPS. Journal Of Elementary Education, 3(4), 21-27.

Jailani, M. S., \& Hamid, A. (2016). Pengembangan Sumber Belajar Berbasis Karakter Peserta Didik (Ikhtiar optimalisasi Proses Pembelajaran Pendidi- kan Agama Islam (PAI)). Jurnal Pendidikan Islam, 10(2).

Khoiriyah, E., \& Sari, E. Y. (2018). Pengembangan Media Pembelajaran Pop-Up Book pada Mata Pelajaran IPA Kelas III SDN 3 Junjung Kecamatan Sumbergempol Kabupaten Tulungagung Tahun Ajaran 2017/2018. Jurnal Bidang Pendidikan Dasar, 2(2), 22-32.

Khoirotun, A., Fianto, A. Y. A., \& Riqqoh, A. K. (2014). Perancangan Buku Pop-Up Museum Sangiran Sebagai Media Pembelajaran Tentang Peninggalan Sejarah. Jurnal Desain Komunikasi Visual, 2(1).

Masturah, E. D., Putu, L., Mahadewi, P., \& Simamora, A. H. (2018). Pengembangan Media Pembelajaran PopUp Book Pada Mata Pelajaran IPA Kelas III Sekolah Dasar Setiap warga negara Indonesia. 6, $212-221$.

Monika, I., Yeni, L. F., \& Ariyati, E. (2014). Uji Aktivitas Ekstrak Kencur terhadap Pengendalian Pertumbuhan Fusarium oxysporum dan Implementasinya Dalam Pembuatan Flipbook. Jurnal Pendidikan dan Pembelajaran Khatuliswa, 3(2), 1-14.

Nurseto, T. (2011). Membuat Media Pembelajaran yang Menarik. Jurnal Ekonomi \& Pendidikan, 8(1), 19-35.

Ramayulis. (2018). Penggunaan Media Gambar Untuk Meningkatkan Minat Belajar PKn Siswa Kelas II SD Negeri 157 Pekanbaru. Jurnal PAJAR (Pendidikan dan Pengajaran) Program Studi Pendidikan Guru Sekolah Dasar FKIP Universitas Riau, 2(2), 214-222. 
Ruiz, C., Le, S. N., \& Low, K. L. (2015). Generating animated paper pop-ups from the motion of articulated characters. Visual Computer, 31(6-8), 925-935. https://doi.org/10.1007/s00371-015-1125-8

Safri, M., Sari, S. A., \& Marlina. (2017). Pengembangan Media Belajar Pop-Up Book Pada Materi Minyak Bumi. Jurnal Pendidikan Sains Indonesia, 5(1), 107-113.

Sholikhah, A. (2017). Pengembangan Media Pop Up Book untuk Meningkatkan Kemampuan Menulis Kreatif pada Mata Pelajaran Bahasa Indonesia Materi Menulis Karangan Kelas V SDN Rowoharjo Tahun Ajaran 2016/2017. Simki-Pedagogia, 1(8), 1-8.

Suwatra, I. W., \& Dkk. (2017). Modul Belajar dan Pembelajaran. Singaraja: Universitas Pendidikan Ganesha.

Tegeh, I M., Nyoman J., \& Ketut P. 2014. Model Penelitian Pengembangan. Singaraja: Graha Ilmu.

Tegeh, I. M., \& Jampel, N. (2017). Metode Penelitian Pengembangan. Singaraja: Universitas Pendidikan Ganesha.

Yamasari, Y. (2010). Pengembangan Media Pembelajaran Matematika Berbasis ICT yang Berkualitas. Seminar Nasional Pascasarjana X, (979). 